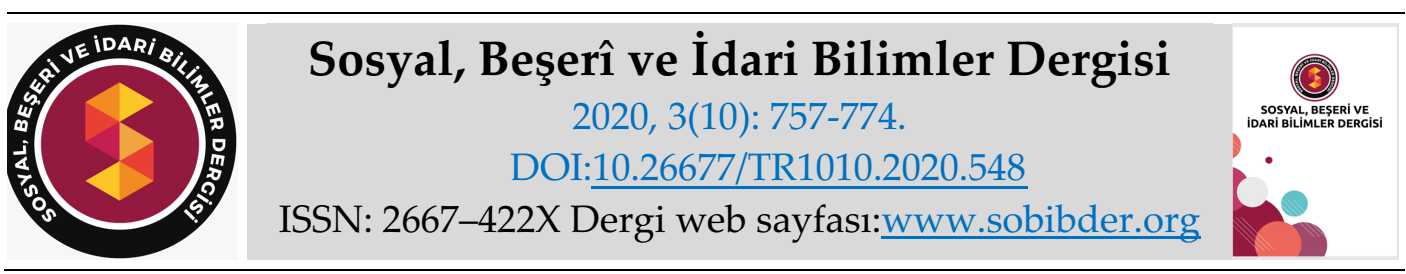

ARAŞTIRMA MAKALESI

\title{
Bilim ve Sanat Merkezlerinde Verilen Eğitimin Aile Görüşlerine Göre Boylamsal Olarak Değerlendirilmesi*
}

Dr. Nida BÜYÜKTOKATLI, Sınıf Öğretmeni, Aksaray Bilim ve Sanat Merkezi, Aksaray, e-posta: nidabuyuktokatli@gmail.com ORCID: https://orcid.org/0000-0001-7105-6085

Doç. Dr. Ahmet KURNAZ, Necmettin Erbakan Üniversitesi, Ahmet Keleşoğlu Eğitim Fakültesi, Konya, e-posta: ahkurnaz@hotmail.com

ORCID: https://orcid.org/0000-0003-1134-8689

Öz

Özel yetenekli çocukların eğitim ve gelişimi üzerinde anne babaların önemli bir rolü vardır. Özel yetenekli öğrencilerin eğitimi Bilim ve Sanat Merkezleri'nde (BİLSEM) yürütülmektedir. Bu çalışmada özel yetenekli çocukların ailelerinin Bilim ve Sanat Merkezi'yle ilgili düşünceleri ve beklentilerinin araştırılması amaçlanmaktadır. Çalışma tarama modelinde boylamsal olarak kesit alma yaklaşımıyla yürütülen nitel bir çalışmadır. Çalışmanın katılımcılarını İç Anadolu bölgesinde bir Bilim ve Sanat Merkezi'ne devam eden 78 öğrenci velisi oluşturmuştur. Nitel araştırma yönteminin kullanıldığı çalışmada, veriler açık uçlu sorulardan oluşan "Özel Yetenekli Öğrenci Ailelerinin BİLSEM'e Yönelik Görüşleri" sabit form görüşme anketi ile elde edilmiştir. Veriler, betimsel analiz yöntemi ile analiz edilmiştir. Araştırma verilerine göre, BİLSEM'e yönlendirmenin ailenin farkındalığının yanı sıra çoğunlukla örgün eğitim öğretmenleri tarafından yapıldığı sonucu göze çarpmaktadır. Velilerin BİLSEM'e ilişkin zaman ve yorucu olması adına olumsuzlar yaşadıkları; bununla birlikte BİLSEM'in çocuklarının bilimsel, zihinsel, bireysel, akademik, sosyal gelişimi üzerindeki farklı yönleriyle katkıları olduğu ve buna istinaden BİLSEM'e devam etmesini istedikleri sonucuna ulaşılmıştır.

*Bu çalışma daha önce VI. Ulusal Üstün Yeteneklilerin Eğitimi Kongresinde bildiri olarak sunulmuştur.

Anahtar Kelimeler: Zekâ, Özel Yetenekli, BİLSEM, Aile.

Makale Gönderme Tarihi: 03.06.2020

Makale Kabul Tarihi: 02.10 .2020

Önerilen Atıf:

Büyüktokatlı, N. ve Kurnaz, A. (2020). Bilim ve Sanat Merkezlerinde Verilen Eğitimin Aile Görüşlerine Göre Boylamsal Olarak Değerlendirilmesi, Sosyal, Beşeri ve İdari Bilimler Dergisi, 3(10): 757-774.

(C) 2020 Sosyal, Beşerî ve İdari Bilimler Dergisi. 


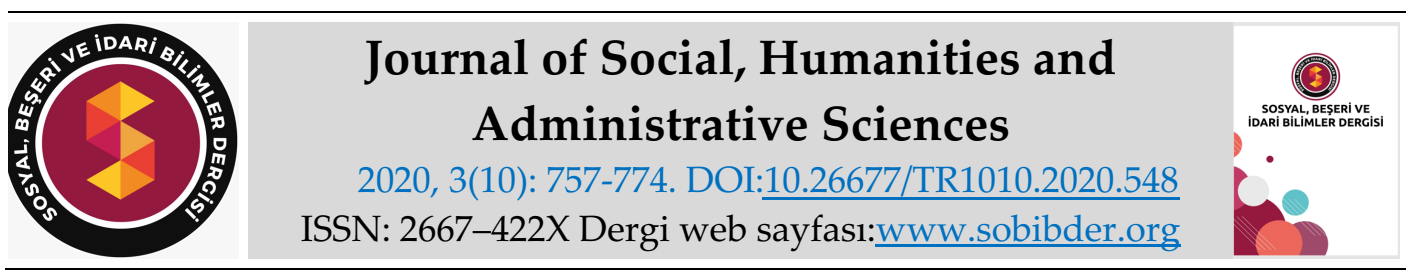

\title{
$\underline{\text { RESEARCH PAPER }}$
}

\section{Longitudinal Evaluation of Education in Science and Art Centers According to Family Views}

Dr. Nida BÜYÜKTOKATLI, Teacher, Aksaray Science and Art Center, Aksaray, e-mail: nidabuyuktokatli@gmail.com ORCID: https://orcid.org/0000-0001-7105-6085

Associate Prof. Dr. Ahmet KURNAZ, Necmettin Erbakan University, Ahmet Keleşoğlu Faculty of Education, Konya, e-mail: ahkurnaz@hotmail.com

ORCID: https://orcid.org/0000-0003-1134-8689

\begin{abstract}
Parents have an important role in training and development of children with special talents. Specially gifted students are educated in Science and Art Centers (BILSEM). In this study, it is aimed to research the thoughts and expectations of families of special gifted children about the Science and Art Center. The study is a qualitative study carried out through cross-sectional approach in the longitudinal approach in the survey model. The participants of the study consisted of 78 gifted parents who attended a Science and Art Center in Central Anatolia. The data were obtained by using the fixed form interview questionnaire and analyzed by descriptive analysis method. According to the research data, it was observed that referral to BILSEM was mostly done by formal education teachers as well as the awareness of the family. Parents had negative effects on BİLSEM to be time and exhausting; However, it has been concluded that BILSEM contributed with different aspects on the scientific, mental, individual, academic and social development of its children with other aspects. Because of these contribution and benefits, parents wanted their children to continue Bilsem.
\end{abstract}

Keywords: Intelligence, Gifted, BİLSEM, Family.

Received: 03.06.2020

Accepted: 02.10.2020

Suggested Citation:

Büyüktokatlı, N. and Kurnaz, A. (2020). Longitudinal Evaluation of Education in Science and Art Centers According to Family Views, Journal of Social, Humanities and Administrative Sciences, 3(10): 757-774.

(c) 2020 Sosyal, Beşerî ve İdari Bilimler Dergisi. 


\section{GİRIŞ}

Geçmişten günümüze birçok devlet bilim, sanat ve spor gibi alanlarda üstün ve özel yeteneklilerin eğitimine oldukça önem vermişlerdir. Toplumların yükselmesinde ve gelişmesinde, sanat, eğitim, bilim ve teknoloji gibi alanlarda üstün yetenekli bireylerin katkısı göz ardı edilemez bir gerçektir. Üstün yetenekli çocukların eğitimine katkıda bulunmak, onların sahip oldukları bu üstün yetenekleri belirlemek, geliştirmek, doğru yönlendirmek ve bu bireylerin ihtiyaçlarını karşılamak ülkemizin ve insanlığın yararına olacaktır (Ciğerci, 2006:1). Üstün yeteneklilerin eğitimi gelişmiş ülkelerde üzerinde önemle durulan bir konudur. Çünkü bu öğrencilerin doğru ve uygun şekilde yetiştirilmesi hem ülkelerine hem de insanlığa önemli katkılar getirmektedir (Çitil, 2018:144). Üstün yetenekli kişiler toplumun en büyük zenginliğidir. Topluma her alanda yön verecek olan bu kişilerdir. İnsanının yeteneklerini, zekâsını, gücünü bilmeyen ve bunları iyi değerlendiremeyen toplumların gelişme, çağdaşlaşma, önder olma iddiaları olamaz (Çelikten, 2017:99). Türkiye'nin üstün yeteneklilerin eğitimini gerçekleştirecek atılım gücüne ulaşarak bilgi üretimine başlaması, mevcut sorunları aşması ve ülke ölçekli stratejilerin geliştirilmesi için somut adımları atmaya yönelmesi hem zorunlu hem de gereklidir (Bakioğlu ve Levent, 2013:43). Cumhuriyet tarihimize baktığımızda da özel yetenekli bireylerin eğitimlerine önem verildiği görülmektedir. Yasalardaki çeşitli düzenlemelerle, bu özel kişilere çeşitli fırsatlar yaratılmıştır. Türk eğitim tarihinde özel yetenekliler için bu imkânlar kısaca özetlenirse Nizamiye Medreseleri, Enderun Okulu, 6660 sayılı müzik, resim ve diğer güzel sanat dallarında olağanüstü yetenek gösteren çocukların devletçe eğitilmesini düzenleyen yasa, Fen liseleri, Ankara Rehberlik ve Araştırma Merkezi'nin 1964 yılından itibaren 5 yıl süre ile bazı ilkokullarda özel sınıf ve türdeş kümeler denemesi, 1416 sayılı yasa, Güzel Sanatlar Liseleri, Sosyal Bilimler Liseleri ve Anadolu liseleri uygulamaları sayılabilir (ORGM/MEB, 2013, Akt: Kurnaz, 2014:1). Bilim ve Sanat Merkezi (BİLSEM); “Okul öncesi eğitim, ilkokul, ortaokul ve lise çă̆ındaki özel yetenekli öğrencilerin bireysel yeteneklerinin farkında olmaları ve kapasitelerini geliştirerek en üst düzeyde kullanmaların sağlamak amacıyla yerleşim biriminin özellikleri, ulaşım imkânları ve bölgesel olarak nüfusunun 100.000'den az olmaması şartı ile hizmet alması öngörülen öğrenci sayısı gibi hususlar da dikkate alınarak valiliklerin teklifi üzerine Bakanlıkça açılmış olan bağımsız özel eğitim kurumudur" (MEB, 2016). Türkiye'de ilk olarak 1994-1995 eğitim öğretim yılında Ankara'da Yasemin Karakaya Bilim ve Sanat Merkezi açılmış olup, şu anda Türkiye genelinde toplam 139 Bilim ve Sanat Merkezi özel yetenekli çocuklara eğitim vermektedir.

Türkiye'de üstün yetenekli öğrenciler için varolan okul sonrası programların başında Milli Eğitim Bakanlığı tarafından yürütülen ve ülke genelinde yaygın olarak yer alan Bilim Sanat Merkezleri (BİLSEM), üniversite kampüslerinde yürütülen araştırma ve eğitim merkezleri ve özel sektör tarafından yürütülen merkezler bulunmaktadır (Sak vd., 2015:119). Bilim ve Sanat Merkezleri uygulamada müfredat zenginleştirmeleriyle öğrencilerin yaratıcılıklarını geliştirmeye çalışmakta, ayrıca öğrencileri bir bütün olarak ele alıp duygusal ve sosyal yönden de gelişmelerini sağlayacak etkinlikleri müfredatla bütünleştirmektedir. Bu eğitim; gerçek yaşam ve sorun durumlarını ilgililerle birlikte teşhis etmek, çözüm önerileri üretmek, bunları uygulamak ve değerlendirme raporlarını yazmak gibi aşamalardan oluşan proje çalışmaları ile hem yaparak yaşayarak öğrenmeye olanak vermekte, hem de endüstrinin genç yeteneklerden yararlanmasına firsat sağlamaktadır (Özbay, 2013:88). Böylelikle öğrencilerin toplumla bütünleşmesi kendi okullarında sağlanırken; BİLSEM'ler aracılığıyla da yeteneklerini fark etmeleri ve bu yeteneklerinin geliştirilmesine yönelik eğitim almaları sağlanmaktadır (Keskin, Samancı ve Aydın, 2013:82).

Toplam nüfusun \%2'lik bir kısmını oluşturan üstün zekâlı ve üstün yetenekli çocukların yeteneklerini geliştirerek, kapasitelerini en üst düzeyde kullanmalarını sağlamak için açılan Bilim ve Sanat Merkezleri üstün zekâlı ve üstün yetenekli çocukların bugünü ve geleceği açısından 
kuskusuz ayrı bir önem taşımaktadır (Koç, 2016:3). Üstün yetenekli çocukların eğitim ve gelişimi üzerinde anne babaların önemli bir işlevi vardır. Üstün yetenekli çocuğun işlevlerini yerine getirmesi, yaşamdan doyum sağlayan mutlu ve dengeli birey olarak yetişmesi aile içi ilişkiler ve anne babaların tutumları ile ilişkilidir. Özellikle yaşıtlarından farklı özellikleri olan üstün yetenekli çocuklara sahip anne babaların çocuklarının eğitimi ve olası sorunları önlemek için daha fazla bilince gereksinim duydukları gözlenmektedir (Karakuş, 2010:129). Bilim ve Sanat Merkezleri ile ilgili veli görüşlerinin alınması ve beklentilerinin tespit edilmesi özel yetenekli öğrencilerin eğitimleri süresince karşılaştıkları sorunların çözümü adına oldukça önem arz etmektedir. Bu bağlamda bu araştırmada özel yetenekli öğrencilerin yeteneklerini geliştirmeleri doğrultusunda eğitim aldıkları Bilim ve Sanat Merkezleri'nin velilerin gözüyle incelenmesini amaçlanmıştır. Özel yetenekli öğrenci ailelerinin BİLSEM hakkındaki görüşlerinin eğitimcilere ve araştırmacılara önemli veriler sunacağı düşünülmektedir.

\section{Araştırmanın Amacı}

Bu çalışmada özel yetenekli çocukların ailelerinin Bilim ve Sanat Merkezi ile ilgili düşünceleri ve beklentilerinin araştırılması amaçlanmaktadır. Bu genel amaç doğrultusunda; BİLSEM işleyişi hakkında veli görüşleri, BİLSEM velilerinin özel yetenekli çocukları ile etkileşimi, velilere göre BİLSEM' in öğrenci gelişimi üzerindeki etkileri ve BİLSEM'in örgün eğitim arasındaki iş birliğinin nasıl yürütülmekte olduğu incelenecektir.

\section{YÖNTEM}

Bu bölümde bu araştırmanın deseni, çalışma grubu, veri toplama araçları ve veri analizleri ile ilgili bilgiler sunulmaktadır.

\section{Araștırma Modeli}

Bu çalışma özel yetenekli çocukların ailelerinin Bilim ve Sanat Merkezi'yle ilgili düşünceleri ve beklentilerinin araştırılması amacıyla yapılan tarama modelinde boylamsal olarak kesit alma yaklaşımıyla yürütülen nitel bir çalışmadır. Kesit alma yaklaşımında, çeşitli gelişmişlik evrelerini temsil ettiği kabul edilen, birbirinden ayrı gruplar üzerinde ve bir anda yapılacak gözlemlerle belirlenmeye çalışılır (Karasar, 2004:80).

\section{Çalışma Grubu}

Çalışmanın katılımcılarını İç Anadolu bölgesinde bir Bilim ve Sanat Merkezi'ne devam eden 78 özel yetenekli öğrenci velisi oluşturmuştur. Çalışmada 48 kişiden oluşan 1. yıl veli grubu, 14 kişiden oluşan 2. yıl veli grubu, 16 kişiden oluşan 3. yıl ve üzeri veli grubu olmak üzere üç farklı veli grubunun görüşleri incelenmiştir. Velilerin sayı dağılımlarına bakıldığında, 1. yıl veli grubunun 2019-2020 eğitim öğretim yılında BİLSEM tanılaması yapılan öğrenci sayılarının diğer yıllara nazaran daha fazla olması nedeniyle daha çok olduğu görülmektedir. Diğer veli gruplarının ise o yıllarda tanılaması yapılan öğrenci sayısının daha az olmasından ötürü düşük olduğu söylenebilir. 


\section{Veri Toplama Aracı}

Nitel araştırma yönteminin kullanıldığı çalışmada, veriler açık uçlu sorulardan oluşan "Özel Yetenekli Öğrenci Ailelerinin BİLSEM'e Yönelik Görüşleri" sabit form görüşme anketi ile elde edilmiştir. Görüşme formu toplam 15 adet sorudan oluşmakta olup, katılımcılara ait birtakım demografik bilgilerde yer almaktadır.

\section{Verilerin Analizi}

Araştırmada elde edilen veriler analiz edilirken nitel araştırma modelinin analiz yöntemlerinden betimsel analiz tekniğinden yararlanılmıştır. Betimsel analiz, verilerin analizi sonucunda ortaya çıan bulguları düzenleyerek okuyucuya aktarmak amacıyla yapılmıştır. Analiz sürecinde var olan durumu betimlemek amacıyla araştırmacı tarafından bir kodlama tablosu oluşturulmuş, veriler kodlanarak tabloya işlenerek kodların frekans ve yüzdeleri de tabloda sunulmuştur. Bulgularda yer alan veli görüsslerine ait alıntılar 1. yıl veli grubu temsilen; A1, A2, A3...., 2. yıl veli grubu temsilen; B1, B2, B3....., 3. yıl ve üzeri veli grubu temsilen; C1, C2, C3..... şeklinde kodlanarak sunulmuştur.

Nitel verinin sayısallaştıılmasında birkaç temel amaç vardır. Bunlardan birincisi, sayısallaştırmanın güvenirliği arttırmasıdır. Ayrıca analiz sonucunda ortaya çıkacak yorumların daha adil bir biçimde yapılmasını, ortaya çıkan sonuçlar arasında daha net karşılaştırma yapmamızı sağlayabilir (Yıldırım ve Şimşek, 2005:242). Bu nedenle araştırma bulgularında betimlemeler yaparken bazı veriler sayısallaştırılarak okuyucuya sunulmaktadır.

\section{Geçerlik ve Güvenirlik}

Araştırmanın bilimsel olarak kabul edilebilmesi için araştırma sürecinin ve sonuçlarının açık, tutarlı ve başka araştırmacılar tarafından teyit edilebilir olması gerekir (Yıldırım ve Şimşek, 2005:265). Araştırma kapsamında verilerin analiz edilmesi sürecinde ortaya çıkan kodlar iki araştırmacı tarafından farklı zamanlarda yapılarak araştırmanın nesnelliği sağlanmıştır.

\section{BULGULARve YORUM}

\section{BİLSEM'in İşleyişi Hakkında Veli Görüşlerine Ait Bulgular}

Özel yetenekli çocuklarının BİLSEM'e yönlendirilmelerinde nelerin etki ettiği, BİLSEM hakkında merak edilenler, BİLSEM hakkında olumsuz düşüncelerinin olup olmadığı, BİLSEM'e devam etme sebepleri ve ebeveyn olarak BİLSEM velisi olmanın nasıl bir etki oluşturduğuna dair bulgular bu başlık altında incelenmiştir.

Tablo 1. Aileyi BİLSEM'e Yönlendiren Durumlar

\begin{tabular}{|c|c|c|c|c|c|c|}
\hline \multirow{2}{*}{ Kodlar } & \multicolumn{2}{|l|}{ 1. y1l } & \multicolumn{2}{|l|}{ 2. y1l } & \multicolumn{2}{|c|}{3 yıl ve üzeri } \\
\hline & Siklık & $\%$ & Siklık & $\%$ & Siklık & $\%$ \\
\hline Çocuk isteği & 2 & 4 & 1 & 7,14 & 0 & 0 \\
\hline Beklenti & 8 & 16 & 3 & 21,42 & 6 & 31,57 \\
\hline Öğretmen yönlendirmesi & 26 & 52 & 5 & 35,71 & 6 & 31,57 \\
\hline Aile farkındalığ 1 & 12 & 24 & 2 & 14,28 & 2 & 10,52 \\
\hline BİLSEM sınavını kazanması & 1 & 2 & 0 & 0 & 2 & 10,52 \\
\hline $\begin{array}{l}\text { Evde yeterli olamama/örgün } \\
\text { eğitimdeki eksiklikler }\end{array}$ & 1 & 2 & 3 & 21,42 & 3 & 15,78 \\
\hline Toplam & 50 & 100 & 14 & 100 & 19 & 100 \\
\hline
\end{tabular}


Araştırma verilerine göre öğrenciler BİLSEM'e genel olarak öğretmenler tarafından yönlendirilmektedir. Öğretmen yönlendirmesinin oranı 1. yıl veli grubunda \%52 iken, diğer veli grubunda bu oranın daha düşük düzeyde olduğu görülmektedir. BİLSEM'e yönlendirmenin öğretmen tarafından yapıldığını $A 7$ "Öncelikle okul öğretmenimizin yönlendirmesi ve BILLSEM ile ilgili yaptı̆̆ım araştırmalar neticesinde oluşan kanaat bizi yönlendirdi." şeklinde ifade etmiştir. C12 ise BILLSEM tanılama sürecini "Eşimin çocuğumuzdaki farkl yönleri tespit etmesinden sonra BILLSEM seçmelerine katıldık ve okuldaki öğretmeninin de desteğiyle BíLSEM hakkında bilgi sahibi olduk." cümleleriyle açıklamıştır. Bunun yanı sıra 1. yıl veli grubunun (\%24) daha yüksek oranda çocuklarında var olan yetenek ile ilgili farkındalıkları olduğunu dile getirdikleri belirlenmiştir. Bu doğrultuda $A 25$ tanılama sürecini "Çocuğumun özel yetenekli olduğunu düşündüğ̈̈mden dolayı BILLSEM'de kendi gibi olan arkadaşlarıyla vakit geçirebilmeleri ve projelerde yer almaları adına BILLSEM'e yönlendirdik." cümleleriyle ifade etmiştir. BİLSEM'e yönlendiren diğer bir unsur öğrencilere ailelerin okul dışında yeterli olamaması ve örgün eğitimin özel yetenekli öğrencilere uygun olamamasıdır. Bu bulgunun 2. yıl veli grubu tarafından (\%21,42) diğer veli gruplarına göre daha yoğunlukla ifade edildiği görülmektedir. Bu bulguya istinaden B9'un"Gittiği okulda aldığı eğitim yeterli olmadığın ve özel yeteneklerini BíLSEM'in karşılayacă̆g düşüncesi ile buraya yöneldik." şeklindeki ifadesi örgün eğitimdeki eksiklikten ötürü yönlendirildikleri görülmektedir.

Tablo 1. BİLSEM Hakkında Merak Edilenler

\begin{tabular}{|c|c|c|c|c|c|c|}
\hline \multirow{2}{*}{ Kodlar } & \multicolumn{2}{|l|}{ 1. y1l } & \multicolumn{2}{|l|}{ 2. y1l } & \multicolumn{2}{|c|}{3 yıl ve üzeri } \\
\hline & S1kl1k & $\%$ & Siklık & $\%$ & Siklık & $\%$ \\
\hline Etkinlik içerikleri & 8 & 18,60 & 1 & 11,11 & 1 & 7,14 \\
\hline Öğretmen yeterliliği & 3 & 6,97 & 0 & 0 & 3 & 21,42 \\
\hline Çocuk için katkıları & 20 & 46,51 & 4 & 44,44 & 1 & 7,14 \\
\hline $\begin{array}{l}\text { Sinavlar ve BİLSEM'ir } \\
\text { geleceği }\end{array}$ & 1 & 2,32 & 1 & 11,11 & 7 & 50 \\
\hline Eğitim şekli & 11 & 25,58 & 3 & 33,33 & 0 & 0 \\
\hline BİLSEM tanılama süreci & 0 & 0 & 0 & 0 & 2 & 14,28 \\
\hline Toplam & 43 & 100 & 9 & 100 & 14 & 100 \\
\hline
\end{tabular}

Tablo 2 incelendiğinde velilerin genel olarak BİLSEM'de yapılan etkinlik içeriklerini ve eğitim şeklini merak ettikleri bulgusuna ulaşılmıştır. B11, "Nasıl bir eğitim verildiğini merak ediyorum." şeklinde belirtirken; A16 "Sinfflar, ders içerikleri ve öğretme metotlar nelerdir? Çocuklar ile öğretmenlerin iletişimlerinin nasıl olduğu gibi şeyleri merak ediyorum." diyerek farklı yönleriyle merak ettiği unsurları açıklamıştır. Özellikle 1. yıl olan velilerin bu bağlamda daha yeni olmalarından kaynaklı olarak etkinlik içeriklerine istinaden merak düzeylerinin $(\% 18,6)$ daha yüksek olduğu görülmektedir. Etkinlik içerikleri ile ilgili olarak 2. yıl veli grubunun (\%11,11); 3. yıl ve üzeri veli grubunun ise $(\% 7,14)$ olarak bu konudaki merak düzeylerinin düşmekte olduğu görülmektedir. Ayrıca BİLSEM' in çocuk için sağlayacağı katkıların da veliler tarafından merak edilenler arasında önemli bir unsur olduğu göze çarpmaktadır. 3. yıl ve üzeri veli grubunun diğerlerine göre daha yüksek oranda $(\% 21,42)$ öğretmenlerin yeterliliği hakkında merak ve endişelerini dile getirdikleri bulgusuna ulaşılmıştır. B5'in "Her birimin üniversitelerle olan bağlantı ve gerekli koordinasyonun olup olmadığını merak ediyorum. Öğretmenler her alanda gerekli faydayı sağlayabiliyor mu ?" şeklide ifadesi farklı alan öğretmenlerinin uygulamaları ile ilgili olarak endişeleri olduğu görülmektedir. Yine benzer şekilde 3. yıl ve üzeri veli grubunun diğerlerine göre daha yüksek oranda (\%50) sinavlar ve BİLSEM'in geleceği hakkında yüksek oranda merak duydukları göze çarpmaktadır. Bu bulguya istinaden C2' nin "Şu an için değil ama ilerde BİLSEM'de kayıtl öğrencilerin pozitif ayrımcllı̆̆a 
tabi olup olmayacağını, BILLSEM'in onlara doğrudan avantaj sağlayıp sağlamayacağını merak ediyorum." ifadesi örnek verilebilir.

Tablo 2. BİLSEM'e İlişkin Olumsuz Görüşler

\begin{tabular}{|c|c|c|c|c|c|c|}
\hline \multirow{2}{*}{ Kodlar } & \multicolumn{2}{|l|}{ 1. y1l } & \multicolumn{2}{|l|}{ 2. y1l } & \multicolumn{2}{|c|}{3 yıl ve üzeri } \\
\hline & S1klik & $\%$ & Siklık & $\%$ & Siklik & $\%$ \\
\hline Okulun yetersizliği & 2 & 4 & 2 & 13,33 & 2 & 9,52 \\
\hline Öğretmenlere karşı güvensizlik & 4 & 8 & 1 & 6,66 & 1 & 4,76 \\
\hline Zaman problemi & 4 & 8 & 6 & 40 & 5 & 23,80 \\
\hline Olumsuzluk yok & 33 & 66 & 6 & 40 & 9 & 42,85 \\
\hline Yorucu olması & 2 & 4 & 0 & 0 & 2 & 9,52 \\
\hline $\begin{array}{l}\text { Öğrenci seçim hakkında şüphe } \\
\text { duyulması }\end{array}$ & 2 & 4 & 0 & 0 & 1 & 4,76 \\
\hline Çevreden duyulan olumsuzluklar & 3 & 6 & 0 & 0 & 1 & 4,76 \\
\hline Toplam & 50 & 100 & 15 & 100 & 21 & 100 \\
\hline
\end{tabular}

Tablo 3 incelendiğinde özellikle 1. yıl veli grubu (\%66) olmak üzere bütün veli gruplarında yüksek oranda BİLSEM ile ilgili olumsuzluk yaşamadıkları bulgusuna ulaşılmıştır. Bununla birlikte bu bulgunun 2. yıl veli grubu $(\% 40)$ ve 3. yil ve üzeri veli grubunda $(\% 42,85)$ olarak azaldığı görülmektedir. Elde edilen olumsuz görüşlere bakıldığında ise özellikle zaman probleminin göze çarptığı, bunun yanı sıra öğrenciler için yorucu olduğunun da sıklıkla veliler tarafından dile getirildiği görülmektedir. Örneğin B9 bunula ilgili olarak "BÍLSEM'in okuldan sonra olması ve derslerin geç saatlerde olması nedeniyle çok yorulacağın düşünüyordum. Ödevi yapmayı sevmiyor ve gerekli görmeyen bir çocuğum olduğu için ödevleri nasıl yapacă̆ı konusunda endişelerimiz vardı." şeklinde ifade ederken; A34 olumsuz görüş olarak "Hem okul hem BILLSEM olması çocuk için yorucu olacaktır." ifadesini kullanmıştır. C1 zaman sorununa ilişkin "Okuldan sonra olmasından dolayı ve çocuğumun yaşının küçüklü̈̆̈̈nden yapamayacă̆ın devam edemeyeceğini düşündüm. Zaman olarak sıkıntılı olması ve çocukların yorgun gelmesi gibi. Bunun dışında öğretmenler hakkında olumsuz şeyler aktaranlar oldu. Bu yüzden olumsuz düşüncelere kapıldım." cümleleriyle yaşanan olumsuzluklardan bahsetmiştir. 2. yıl veli grubunun $(\% 13,33)$ diğer veli gruplarına göre okulun fiziksel donanım ile ilgili yetersizliği konusunda daha fazla görüş belirttikleri görülmektedir. Bu bulguya istinaden B13'ün "Okulun fiziksel olarak daha iyi olması gerekirdi." şeklindeki ifadesi okuldaki fiziki donanım eksikliğinin olumsuzluk olarak görüldüğünü ortaya koymaktadır.

Tablo 3. BíLSEM'e Devam Etme Sebepleri

\begin{tabular}{|c|c|c|c|c|c|c|}
\hline \multirow{2}{*}{ Kodlar } & \multirow{2}{*}{$\frac{\text { 1. y1l }}{\text { Siklık }}$} & \multicolumn{2}{|r|}{ 2. y1l } & \multicolumn{3}{|c|}{3 yıl ve üzeri } \\
\hline & & $\%$ & S1kl1k & $Y \%$ & S1klik & $Y \%$ \\
\hline Çocuk isteği & 6 & 11,53 & 1 & 8,33 & 6 & 28,57 \\
\hline Sinavlardan ek puan beklentisi & 0 & 0 & 3 & 25 & 1 & 4,76 \\
\hline Çocuk için faydalı olması & 30 & 57,69 & 7 & 58,33 & 7 & 33,33 \\
\hline Sosyalleşme ve özgüven & 5 & 9,61 & 1 & 8,33 & 2 & 9,52 \\
\hline Okul dışı destek & 5 & 9,61 & 0 & 0 & 2 & 9,52 \\
\hline BíLSEM'in eğitim felsefesi & 6 & 11,53 & 0 & 0 & 3 & 14,28 \\
\hline Toplam & 52 & 100 & 12 & 100 & 21 & 100 \\
\hline
\end{tabular}


Tablo 4 incelendiğinde veli gruplarının genel anlamda çocuk için faydalı olması sebebiyle BİLSEM'e devam etmek istedikleri bulgusu elde edilmiştir. Bunun yanı sıra 3. yıl ve üzeri veli grubu diğerlerine göre daha yüksek oranda $(\% 28,57)$ çocuklarının istemesi nedeniyle BİLSEM'e devam ettiklerini ifade etmişlerdir. Okul dışı destek alınması isteği sebebiyle 1. yıl veli grubu $(\% 9,61)$ ve 3. yıl ve üzeri veli grubunun $(\% 9,52)$ olarak devam ettikleri görülürken 2 . yıl veli grubundan bu anlamda hiçbir veri elde edilmemiştir. Bazı velilerin çocuklarının farklı bakış açıkları kazanma, sosyalleşme, gelecekte ülkesine yararlı işler yapma gibi ifadeleri BİLSEM için farklı bir eğitim beklentilerinin olduğunu öne çıkartmaktadır. Bu kapsamda B3'ün "Dünyayı daha farklı bir gözle algılaması yeterlidir. Devam ettirmek için bunu bilmek bile benim için yeterli bir sebeptir." ifadesi BİLSEM'in eğitim felsefesi bağlamında değerlendirilmiştir. Çocuğa faydalı olması yönünde $A 15$ "Çocuğumun resim alandaki gelişimini somut şekilde gözlemleme ve yeteneğinde gelişmeyi daha iyi görebilmem." ifadesini kullanmıştır. Çocuk için sağladığı katkılar neticesinde BİLSEM'e devam ettirilme durumu ile ilgili olarak; 1 . yıl veli grubu $(\% 57,69)$ ile 2 . yll veli grubunun $(\% 58,33)$ yakın oranda görüş belirttikleri görülürken, 3. yıl ve üzeri veli grubunda ise bu oranın $(\% 33,33)$ olarak daha az olduğu görülmektedir. Sınavlardan ek puan beklentisi olan veli görüşlerine istinaden ise C10'un "illerleyen yillarda BILSEM'in stnavlara ek puan getirme ihtimali gönderme sebeplerinden biri diyebilirim. Bunun dışında çocuğumun da oldukça istekli olması nedeniyle devam ediyoruz." ifadesi örnek verilebilir.

Tablo 4. BİLSEM Velisi Olmak

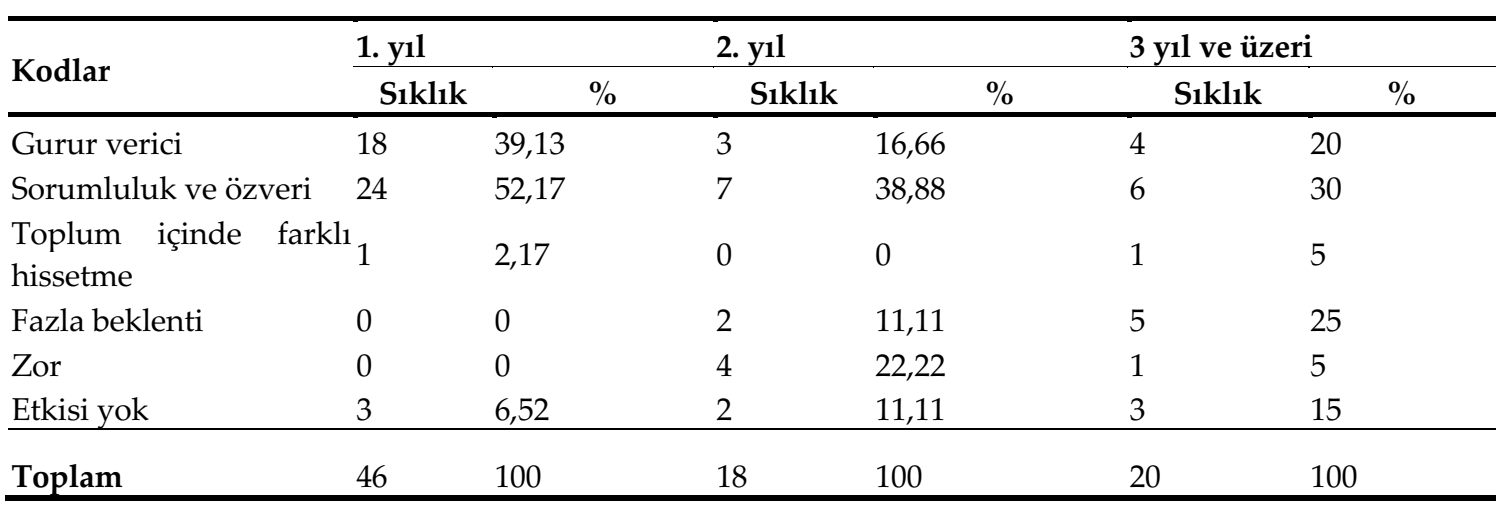

Araştırma verilerine göre Tablo 5'de BİLSEM velisi olmanın özellikle 1. yıl velileri olmak üzere $(\% 52,17)$ veli gruplarının çoğunluğunun sorumluluk ve özveri gerektirdiğini ifade ettikleri görülmüştür. BİLSEM velisi olmanın bir gurur kaynağı olduğunu düşünen veliler 1. yıl veli grubu $\% 39,13$, 2. yıl veli grubu $\% 16,66$ ile 3 . yll ve üzeri veli grubu $\% 20$ düzeyindedir. Bu oranlara istinaden, yeni velilerin BİLSEM velisi olmayı diğer veli gruplarına göre daha fazla gurur kaynağ olarak gördükleri söylenebilir. Bu konuda A18'in "En önemlisi oğlumun başarısını taçlandırılmış olması nedeniyle mutluyum. BILLSEM velisi olmaktan ötürü gururluyum." ifadesi örnek verilebilir. 2. yıl veliler $(\% 22,22)$ gibi diğer veli gruplarından farklı olarak daha yüksek düzeyde özel yetenekli öğrenci velisi olmanın zorluğundan bahsetmişlerdir. Bunun yanı sıra 3. yıl ve üzeri veli grubu diğerlerine göre daha yüksek oranda (\%25) çocukları ile ilgili daha fazla beklenti içinde olduklarını ifade etmişlerdir. Beklenti düzeyinin veli gruplarının dağılımında yıllara göre giderek arttığı da göze çarpmaktadır. Bu durumu C8 “Çocuğumun BİLSEM öğrencisi olduğunu bilmek ister istemez hem gurur duymamı sağhlyor hem de daha iyi şeyler yapacağı yönünde beklentimin yüksek olmasını sağlıyor." cümleleriyle özetlemiştir. A4 ise BİLSEM velisi olmayı "Bir etkisi olduğunu zannetmiyorum." şeklinde açıklamıştır. Konu ile ilgili veli görüşlerinden diğer alıntılara A17'in "Sorumluluk artacaktır diye düşünüyorum. Ekstra uğraşmak, vakit ayırmak gerekebilir ama 
çocuğum için değerli. Çocuğumu mutlu görmek güzel." B9'un "Toplum içinde farkl bir etki oluşturmaktadır. Çocuğumun çok iyi yerlere geleceğini ümit ediyorum." cümleleri örnek verilebilir.

\section{BİLSEM Öğrenci-Veli Etkileşimine Ait Bulgular}

Velilerin özel yetenekli bir çocuğa sahip olmakla ilgili yaşadığı güçlükler ve BİLSEM tanılaması öncesinde çocukları ile nasıl vakit geçirdiklerine ilişkin elde edilen veriler bu başlık altında sunulmuştur.

Tablo 5. Özel Yetenekli Çocuk Ebeveyninin Yaşadığg Güçlükler

\begin{tabular}{|c|c|c|c|c|c|c|}
\hline \multirow{2}{*}{ Kodlar } & \multicolumn{2}{|l|}{ 1. yıl } & \multicolumn{2}{|l|}{ 2. yil } & \multicolumn{2}{|c|}{3 yıl ve üzeri } \\
\hline & Siklık & $\%$ & Sıklık & $\%$ & Siklık & $\%$ \\
\hline İletişim güçlüğü & 0 & 0 & 3 & 11,53 & 2 & 9,52 \\
\hline $\begin{array}{l}\text { Yetersiz kalma/Sorulara ceva } \\
\text { verememe }\end{array}$ & & 17,77 & 1 & 3,84 & 7 & 33,33 \\
\hline Sorun olmuyor & 19 & 42,22 & 7 & 26,92 & 5 & 23,80 \\
\hline $\begin{array}{l}\text { Kuralcı olma } \\
\text { mükemmelliyetçilik }\end{array}$ & $\mathrm{ve}_{6}$ & 13,33 & 3 & 11,53 & 1 & 4,76 \\
\hline Çok soru sorması/ konuşması & 0 & 0 & 8 & 30,76 & 3 & 14,28 \\
\hline İnatçılık & 1 & 2,22 & 2 & 7,69 & 1 & 4,76 \\
\hline Yüksek beklenti getirmesi & 3 & 6,66 & 2 & 7,69 & 1 & 4,76 \\
\hline Dışlanma, akran çatışması & 4 & 8,88 & 0 & 0 & 1 & 4,76 \\
\hline Çevrenin Hasetliği & 1 & 2,22 & 0 & 0 & 0 & 0 \\
\hline Yardım kabul etmeme & 3 & 6,66 & 0 & 0 & 0 & 0 \\
\hline Toplam & 45 & 100 & 26 & 100 & 21 & 100 \\
\hline
\end{tabular}

Tablo 6'da velilerin özel yetenekli olan çocukları ile ilgili olarak yaşadıkları sorunlar incelendiğinde, 1 . yıl veli grubu çoğunlukla $(\% 42,22)$ sorun yaşamadıklarını ifade etmişlerdir. Bu konuda A21 "Hayır, bir güçlük yaşamıyorum çocuğumla birlikte sorduğu sorular sayesinde ben de yeni bilgiler ve beceriler kazanıyorum." açıklamasıyla yaşanılan olası güçlükleri avantaja döndürdüğünden bahsetmiş̧tir. Sorun yaşamama durumu ile ilgili olarak diğer 2. yıl ve 3. yıl ve üzeri veli gruplarına bakıldığında yüzde oranlarının giderek azaldığı görülmektedir. Bu bağlamda özel yetenekli öğrencilerin ailelerinin zaman içerisinde yaşadığ güçlüklerin arttığ söylenebilir. 2. yıl veli grubu ise çoğunlukla $(\% 30,76)$ çocuklarının çok soru sorması ve konuşması; 3 . yıl ve üzeri veli grubu ise çoğunlukla $(\% 33,33)$ çocuklarına karşı yetersiz kalma ve onların sorularına cevap verememekten ötürü sorun yaşadıklarını belirtmişlerdir. Bu bulgulara istinaden C12'nin "Bazı soruları sorduğu anda cevaplayamıyorum. Araştırıp dönüş yapacă̆ımı söylüyorum. Bazen de araştırmayı unuttuğum için beni yargılaması sorun oluyor." Ve A15'in Bunun yanı sıra diğer gruplara nazaran 2. yıl veli grubunun \%11,53 yüzde oranı ile iletişim sorunu yaşadıklarını ifade ettikleri görülmektedir. B14 bu duruma istinaden "Genel itibari ile iletişim sorunları yaşıyoruz." ifadesini kullanmıştır. Dışlanma, akran çatışması yönünde 1. yıl veli grubunun $(\% 8,88)$ oran ile daha yüksek düzeyde güçlük yaşadığ görülmektedir. Bu bulguyla ilişkili olması bakımından $A 3$ özel yetenekli çocuğu ile ilgili yaşadığı güçlüklere dayalı olarak "Kendi sınıf ortamında çok farklı görünüyor, bundan dolayı dışlanıyor." ifadelerini kullanmıştır. 2. yıl veli grubundan ise akran çatışması ve dışlanma durumu ile ilgili herhangi bir veri elde edilememiştir. Ayrıca B10'un "Takıntılı olması, mükemmeliyetçi olmasının yan sıra duygusal oluyorlar. Bu gibi durumlardan ötürü sorunlar olabiliyor." şeklinde ifadesi özel yetenekli çocukların 
bazı özelliklerin aileler tarafından tam anlamıla bilinmediğinden sorun olarak görüldüğünü ortaya koymaktadır.

Tablo 6. BİLSEM Tanılaması Öncesi Ev İçi Etkinlikler

\begin{tabular}{|c|c|c|c|c|c|c|}
\hline \multirow{2}{*}{ Kodlar } & \multicolumn{2}{|l|}{ 1. y1l } & \multicolumn{2}{|l|}{ 2. $\mathrm{y1l}$} & \multicolumn{2}{|l|}{3 yıl ve üzeri } \\
\hline & Frekans & $\%$ & Frekans & $\%$ & Frekans & $\%$ \\
\hline Deney & 2 & 4,34 & 2 & 15,38 & 2 & 7,14 \\
\hline $\begin{array}{l}\text { Ev içi oyunlar ve } \\
\text { geziler }\end{array}$ & & 6,52 & 3 & 23,07 & 6 & 21,42 \\
\hline Lego- yapboz & 6 & 13,04 & 0 & 0 & 3 & 10,71 \\
\hline Akıl ve Zeka oyunları & 17 & 36,95 & 3 & 23,07 & 3 & 10,71 \\
\hline Geliştirm & 5 & 10,86 & 1 & 7,69 & 4 & 14,2 \\
\hline Hiçbir şey & 7 & 15,21 & 2 & 15,38 & 2 & 7,14 \\
\hline İletişim & 1 & 2,17 & 1 & 7,69 & 4 & 14,28 \\
\hline Kitap okuma & 5 & 10,86 & 1 & 7,69 & 4 & 14,28 \\
\hline Toplam & 46 & 100 & 13 & 100 & 28 & 100 \\
\hline
\end{tabular}

Tablo 7 incelendiğinde velilerin BİLSEM tanılaması öncesi ev içerisinde çocukları ile ilgili yaptıkları farklı etkinliklerin neler olduğu sorulduğunda çoğunluk olarak genel anlamda zekâ gelişimine yönelik faaliyetler yaptıkları söylenebilir. 1. yıl veli grubu çoğunlukla $(\% 36,95)$ akıl ve zekâ oyunları; 2 . yıl veli grubu ise çoğunlukla (\%23,07) akıl ve zekâ oyunları, ev içi oyunlar ve geziler; 3. yıl ve üzeri veli grubu ise çoğunlukla $(\% 21,42)$ ev içi oyunlar ve gezilere zaman ayırdıklarını ifade etmişlerdir. Ev içi oyunlar ve gezilere 1. yıl veli grubunun $(\% 6,52)$ daha az zaman ayırdığı görülmektedir. Akıl ve zekâ oyunlarına ayrılan zamanın ise 1 . yıl veli grubu $(\% 36,95)$ için en fazla olduğu; diğer veli gruplarında bu oranın $\% 23,07$ ve $\% 10,71$ olarak giderek daha azaldığı görülmektedir. 3. yıl ve üzeri veli grubu ev içinde iletişime $(\% 14,28)$ diğer veli gruplarına nazaran daha fazla önem vermektedir. C11'in "Çocuğumla sohbetler edip, oyunlar oynuyordum." İfadesi iletişime önem verdiğini göstermektedir. Geziler konusunda B9 "Doğada hayvanlarla ve bitkilerle etkinlik yapıyorduk. Evde kuş, balık besledik. Farkl yerlere gidip kedi, köpeklere baktık. Karınca akvaryumu yaptık, canlıların gelişimin izledik. Tohumdan bitki çıması, ilk neler değişti onlara baktık. Deney sevdiği için deney yaptık. Zaman zaman dikkat geliştirme kitaplarından etkinlikler yaptık." ifadelerini kullanmıştır. Konu ile ilgili veli görüşlerinden diğer alıntılara örnek olarak; A27'nin "Özel setlerle etkinlikler yapıyordum. Satranç oynardık." A5'in "Görsel algı güçlendirme setleri, yapboz oyuncaklar ile uğraşırdık. Bilim merkezine gezi gibi faaliyetleri de severdi." B12'nin "Hayal gücünü geliştirecek oyunlar oynar ve ev içi etkinlikler yapardık." ifadeleri bulunmaktadır.

\section{BİLSEM 'in Öğrenci Gelişimi Üzerindeki Etkilerine Ait Bulgular}

Bilim ve Sanat Merkezi'ne devam eden özel yetenekli öğrencilerin farklı alanlarda aldıkları eğitim ile birlikte gelişim göstermeleri beklenmektedir. Bu bağlamda bu başlık altında velilerin öğrencilerde meydana gelen değişiklikler ile ilgili olarak bilimsel, zihinsel, sosyal, akademik, bireysel gelişim ve okul hayatına etkileri olarak farklı kategorilerde görüşlerine ait bulgular elde edilmiştir. Henüz 1. yıl olan veli grubu için ise BİLSEM'in çocuklarının gelişimi için ne gibi farklılıklar oluşturabileceği üzerine varsayım olarak görüşleri alınmıştır. 
Tablo 7. BİLSEM'in Bilimsel Gelişime Katkıları

\begin{tabular}{lcccccc}
\hline \multirow{2}{*}{ Kodlar } & \multicolumn{1}{l}{ 1. yıl } & \multicolumn{2}{c}{ 2. y1l } & \multicolumn{3}{c}{ 3 yıl ve üzeri } \\
\cline { 2 - 7 } & S1kl1k & \% & S1klık & \% & S1klık & \% \\
\hline Araştırma ve projeler yapma & 10 & 17,85 & 11 & 52,38 & 6 & 33,33 \\
\hline
\end{tabular}

Tablo 8 incelendiğinde bütün veli gruplarında çoğunlukla araştırma ve projeler yapma yönünde çocukların bilimsel gelişimlerinde artış olduğuna dair görüşler göze çarpmaktadır. Bu bulgunun 2. yıl veli grubunda $(\% 52,38)$ daha fazla öne çıtığı görülmektedir. Bu bulguya istinaden $B 7{ }^{\prime}$ nin “ BILLSEM sayesinde çocuğumun proje yapmayı öğrendiğini ve bunu daha da geliştireceğini düşünüyorum." İfadesi örnek verilebilir.

Tablo 8. BILSEM'in Zihinsel Gelişime Katkıları

\begin{tabular}{|c|c|c|c|c|c|c|}
\hline \multirow{2}{*}{ Kodlar } & \multicolumn{2}{|l|}{ 1. yıl } & 2. yil & \multicolumn{3}{|c|}{3 yıl ve üzeri } \\
\hline & Siklık & $\%$ & Siklık & $\%$ & Siklık & $\%$ \\
\hline Zekâ Gelişimi & 11 & 20,75 & 7 & 33,33 & 4 & 28,57 \\
\hline Düşünme Becerileri Gelişimi & 28 & 52,83 & 8 & 38,09 & 5 & 35,71 \\
\hline
\end{tabular}

Tablo 9 incelendiğinde çocukların zihinsel gelişimi ile ilgili olarak bütün veli gruplarında çoğunlukla zekâ gelişimi ve düşünme becerileri gelişimine dikkat çektikleri görülmektedir. Zekâ gelişimine yönelik görüşlerin hemen hemen bütün veli gruplarında benzer oranlarda bahsedildiği söylenebilir. Ayrıca 1. yıl veli grubunun $\% 52,83$ gibi yüksek bir oran ile düşünme beceri gelişimine önem verdikleri görülmüştür.

Tablo 9. BİLSEM'in Sosyal Gelişimine Katkıları

\begin{tabular}{|c|c|c|c|c|c|c|}
\hline \multirow{2}{*}{ Kodlar } & \multicolumn{2}{|l|}{ 1. yıl } & \multicolumn{2}{|l|}{ 2. y1l } & \multicolumn{2}{|c|}{3 yıl ve üzeri } \\
\hline & Siklık & $\%$ & Siklık & $\%$ & Siklık & $\%$ \\
\hline $\begin{array}{l}\text { Yeni arkadaşlar edinme, } \\
\text { sosyalleşme ve iş birliği }\end{array}$ & 18 & 43,90 & 5 & 41,66 & 7 & 46,66 \\
\hline
\end{tabular}

Tablo 10 incelendiğinde, bütün veli gruplarının çoğunlukla BİLSEM'in sosyal gelişimi sağlamada yeni arkadaşlıklar, sosyalleşme ve iş birliği yönünde olumlu etkilerinden söz etmişlerdir. Bu bulguya istinaden bütün veli gruplarında benzer oranlarda sonuçlar elde edilmiştir. Yeni arkadaşlar edinme konusunda A42 "Sımıfından farklı olarak BILLSEM yeni arkadaşları olmasını sağlayacak." ifadesini kullanmıştır.

Tablo 11. BİLSEM'in Akademik Gelişime Katkıları

\begin{tabular}{|c|c|c|c|c|c|c|}
\hline \multirow{2}{*}{ Kodlar } & \multicolumn{2}{|l|}{ 1. y1l } & 2. y1l & \multicolumn{3}{|c|}{3 yıl ve üzeri } \\
\hline & Siklık & $\%$ & Siklık & $\%$ & S1klık & $\%$ \\
\hline Zekâsını verimli kullanma & 9 & 18,75 & 1 & 7,69 & 1 & 7,14 \\
\hline Okul derslerine faydalı & 21 & 43,75 & 9 & 69,23 & 5 & 35,71 \\
\hline
\end{tabular}


Tablo 11 incelendiğinde, bütün veli gruplarının çoğunlukla BİLSEM'in okul derslerine faydalı olması yönüyle akademik gelişim sağladığını ifade etmişlerdir. Bunun yanı sıra 1. yıl veli grubu $(\% 18,75)$ diğer veli gruplarına nazaran daha fazla olmakla birlikte BILSEM sayesinde çocuklarının zekâsını verimli kullanarak dolaylı olarak akademik gelişime fayda sağladığını belirtmişlerdir. BILSEM'in okul derslerine faydalı olması yönünde 2. yıl veli grubu $(\% 69,23)$ görüşlerinin diğer gruplara göre daha fazla öne çıtığ 1 görülmektedir. Bu bağlamda veli görüşlerinden B14'ün "BILLSEM her ders için olmasa da çoğunlukla okuldaki derslerinde daha başarılı olmasını sağlıyor." ifadesi örnek verilebilir.

Tablo 12. BILSEM'in Bireysel Gelişime Katkıları

\begin{tabular}{|c|c|c|c|c|c|c|}
\hline \multirow{2}{*}{ Kodlar } & \multicolumn{2}{|l|}{ 1. y1l } & 2. $\mathrm{yll}$ & \multicolumn{3}{|c|}{3 yıl ve üzeri } \\
\hline & Siklık & $\%$ & Siklık & $\%$ & Siklık & $\%$ \\
\hline İletişim /sosyalleşme & 0 & 0 & 4 & 23,52 & 6 & 35,29 \\
\hline Özgüven & 4 & 10,52 & 5 & 29,41 & 2 & 11,76 \\
\hline Girişimcilik & 8 & 21,05 & 0 & 0 & 2 & 11,76 \\
\hline
\end{tabular}

Tablo 12 incelendiğinde, 1 . yıl veli grubu çoğunlukla $(\% 35,29)$ iletişim ve sosyalleşme; 2 . yıl veli grubu çoğunlukla $(\% 29,41)$ özgüven; 3 . yıl ve üzeri veli grubu ise çoğunlukla $(\% 21,05)$ girişimcilik ile ilgili BíLSEM'in çocuklarının bireysel gelişimlerine olumlu etki ettiğini ifade etmişlerdir.

Tablo 13. BİLSEM'in Okul Hayatına Etkileri

\begin{tabular}{|c|c|c|c|c|c|c|}
\hline \multirow{2}{*}{ Kodlar } & \multicolumn{2}{|l|}{ 1. yıl } & \multicolumn{2}{|l|}{ 2. y1l } & \multicolumn{2}{|c|}{3 yıl ve üzeri } \\
\hline & Siklık & $\%$ & Siklık & $\%$ & S1kl1k & $\%$ \\
\hline Uygun meslek/hedef seçme & 8 & 18,60 & 4 & 25 & 13 & 61,90 \\
\hline Disiplinli/iyi bir eğitim hayatı & 9 & 20,93 & 6 & 37,5 & 1 & 4,76 \\
\hline Ek puan ihtimali / burs imkânı & 3 & 6,97 & 2 & 12,5 & 0 & 0 \\
\hline
\end{tabular}

Tablo 13 incelendiğinde, 3 . yıl veli grubu çoğunlukla $(\% 61,9)$ çocuklarının uygun meslek ve hedef seçmeleri; 2. yıl veli grubu çoğunlukla $(\% 37,5)$ disiplinli/iyi bir eğitim hayatı sağlaması ve ek puan ihtimali ya da burs imkanı gibi BİLSEM'in çocuklarının okul hayatına farklı şekillerde etkileri olduğunu ifade etmişlerdir. Tablo-4 incelendiğinde, BİLSEM'e devam etme sebebi olarak sinavlardan ek puan ihtimali olması yine benzer şekilde (\%25) oran ile en fazla 2. yıl veli grubunun görüşlerinde öne çıkmaktadır.

\section{BİLSEM ile Örgün Eğitim İş Birliğine Ait Bulgular}

Öğrencilerin örgün eğitime devam ettikleri okulda bulunan öğretmenlerin özel yetenekli çocuklar ile ilgili veli iş birliğine ilişkin veriler bu başlıkta sunulmuştur.

Tablo 14' de BİLSEM'in örgün eğitimle birlikte iş birliği içinde olması ile ilgili veli görüşlerine yer verilmiştir. Bütün veli gruplarının çoğunlukla örgün eğitimdeki öğretmenlerin oldukça ilgili ve destek sağlamakta olduğunu ifade ettikleri görülmektedir. Özellikle 2. yıl veli grubunun (\%50) oranıla diğer veli gruplarına oranla daha fazla örgün eğitim öğretmenlerinden memnun oldukları söylenebilir. Bu bulguya istinaden C6'nın "illkokul öğretmenimiz çok ilgili bir başarılıydı." 
ve B9'un "Yeterliliği yüksek ve ilgisi yüksek çok memnunuz." ifadeleri örnek verilebilir. Tam tersine bütün veli gruplarında benzer oranlarda olmak üzere örgün eğitimdeki öğretmenlerinin ilgisiz ve özel yetenekliler hakkında bilgisiz olduğuna dair veli görüşlerine de rastlanmıştır. Örgün eğitimde öğretmenler özel yetenek konusunda yetersiz olması ve bilgi eksikliği hakkında B8 "illkokullarda yetenek temelli kadrolaşma yok. Yani okullarında çocuğumun yeteneği doğrultusunda değerlendirme yapacak bir Görsel Sanatlar öğretmeni yok." ifadelerini kullanmıştır. Ayrıca yetersiz olma dışında 3. yıl ve üzeri veli grubunun $(\% 16,66)$ örgün eğitim öğretmenlerinin BİLSEM'e karşı önyargılı ve karşı olduklarını dile getirmişlerdir. C12'nin “Örgün eğitimdeki öğretmenler BILLSEM'i tam olarak anlamadıkları için bu konuda bize yardımo olmuyorlar. Hatta bazen işleri güçleştiriyorlar. BİLSEM olduğu ertesi günü yazll stnav koyuyorlar ya da BİLSEM günü daha fazla ödev veriyorlar." cümleleri bu durumu özetler niteliktedir. 1. yıl veli grubu da tanılama sürecinde örgün eğitim öğretmenleri ile iletişim sorunu $(\% 15,68)$ yaşadıklarını belirtmişlerdir. Okulun ve BíLSEM'in bütünleştirilmesi gerektiğine inanan $C 1$ bu durumu "Henüz bugünkü şartlardan kendi okullarındaki öğretmenlerince veya Milli Eğitim Bakanlığı sistemince tek okul şeklinde tüm ülkemize yayginlaşmadı̆̆ sürece BILLSEM'i okul olarak değil bir eğlence merkezi gibi görmektedir. Mutlu olarak buraya gelmeleri veli olarak beni sevindiriyor ancak eğitime bütünlük katmıyor." cümleleri ile ifade etmiştir.

Tablo 14. Örgün Eğitimde Özel Yetenekli Öğrencilerin Durumu

\begin{tabular}{|c|c|c|c|c|c|c|}
\hline \multirow{2}{*}{ Kodlar } & \multicolumn{2}{|l|}{ 1. y1l } & \multicolumn{2}{|l|}{ 2. yil } & \multicolumn{2}{|c|}{3 yıl ve üzeri } \\
\hline & Siklik & $\%$ & Siklık & $\%$ & S1klık & $\%$ \\
\hline Okul ve BİLSEM bütünleştirilmeli & 0 & 0 & 0 & 0 & 1 & 5,55 \\
\hline $\begin{array}{l}\text { Okuldaki öğretmenler oldukça ilgili ve } \\
\text { destek sağlamakta }\end{array}$ & 19 & 37,25 & 8 & 50 & 7 & 38,88 \\
\hline $\begin{array}{l}\text { Örgün eğitimde öğretmenler özel } \\
\text { yetenek } \\
\text { eksikliği }\end{array}$ & $\begin{array}{l}1 \\
\text { i } 13\end{array}$ & 25,49 & 4 & 25 & 5 & 27,77 \\
\hline $\begin{array}{l}\text { Okuldaki öğretmenler BİLSEM'e karşı } \\
\text { önyargılı }\end{array}$ & ${ }^{1} 1$ & 1,96 & 0 & 0 & 3 & 16,66 \\
\hline Konu hakkında fikrim yok/kararsızım & 10 & 19,60 & 4 & 25 & 2 & 11,11 \\
\hline Tanılama sürecinde iletişim sorunu & 8 & 15,68 & 0 & 0 & 0 & 0 \\
\hline Toplam & 51 & 100 & 16 & 100 & 18 & 100 \\
\hline
\end{tabular}

\section{TARTIŞMA, SONUÇ ve ÖNERİLER}

Araştırma sonrası elde edilen bulgulara istinaden BİLSEM'e öğrencilerin yönlendirilmesinde çoğunlukla örgün eğitimdeki sınıf öğretmenlerin yönlendirmesinin olduğu sonucuna ulaşılmıştır. Benzer şekilde Gökdemir (2017) tezinde BíLSEM'e aday gösterilmesi sürecinde velilerin \%46,66'sının bilgilendirmeyi sınıf öğretmeni ve okul tarafından aldıkları sonucuna ulaşmıştır. Alkan (2013) çalışmasında BİLSEM yönlendirilmesinde etkili olanları belirlemek amacıyla velilerin görüşlerini aldığında, öğretmen ve velilerin bu çocukların belirlenmesinde etkili olduğunu ifade etmiştir. Şahin ve Kargın (2013) çalışmalarında; Türkiye'de genel eğitim okulları birinci kademe sınıf öğretmenlerinin üstün yetenekli bireylerin belirlenmesine ilişkin aldıkları eğitimleri incelendiğinde, sınıf öğretmenliği programlarında lisans düzeyinde üstün yetenekli/zekâlı çocuklar isimli herhangi bir ders bulunmadığı görülmediğini belirtmektedirler. Bilim ve Sanat Merkezleri'ne üstün yetenekli öğrencilerin yönlendirilmesi ile ilgili olarak sınıf öğretmenlerinin önemi düşünüldügüünde bu konuda sınıf öğretmeni adaylarına lisans düzeyinde dersler verilmesi önerilebilir. Böylelikle hem üstün yetenekli öğrencilerin yönlendirilmesi hem 
de sınıf içerisinde zenginleştirilmiş eğitim konusunda öğretmen adaylarının bilgilendirilmesi sağlanacaktır.

Veli gruplarına BİLSEM ile ilgili neleri merak ettikleri sorulduğunda, öğrenciye katkılarının neler olacağının özellikle yeni veliler tarafından daha çok merak edildiği sonucuna ulaşılmıştır. Bununla birlikte BİLSEM etkinlik içerikleri ve eğitim şeklinin nasıl olduğunun diğer veli grupları için en çok merak edilen unsurlar olarak görülmüştür. Etkinlik içerikleri ve eğitim şeklinin nasıl olduğu konusunda velilerin bilgi sahibi olmadıkları sonucuna istinaden alanyazında benzer sonuçlar görülmektedir. Velilerin BİLSEM'in işleyişi konusunda bilgi sahibi olmamalarını Karakuş (2010), Kurnaz, (2014) ve Koç'un (2016) yaptıkları çalışmalar desteklemektedir. Yine benzer şekilde Çamdeviren (2014) tezinde velilerin bilim ve sanat merkezinde uygulanan eğitim programından habersiz olduklarını, kendileriyle daha sık işbirliği yapılması gerektiği sonucuna ulaşmıştır. Velilerinin özel yetenekli çocuklar ve BILLSEM hakkında yeterince bilgi sahibi olmamasından kaynaklanan sorunların giderilmesi adına bilgilendirme çalışmaları yapılarak aile eğitimleri verilebilir. Sak ve diğerleri (2015) bütün BİLSEM'lerde uygulanan ortak, standart bir programın bulunmaması sorununa değinmişlerdir. Her bir BiLSEM'de uygulanan program türleri, ders içerikleri ve proje çalışmaları öğretmenlerin tercihlerine bırakılmıştır. Bu nedenle velilerin program ve etkinlik içerikleri ile ilgili merak ettiklerinin ortak bir cevabı olmadığını ortaya çımaktadır. Buna istinaden düzenlemeler yapılması ve konuyla ilgili farklı araştırmaların yapılması önerilebilir.

BİLSEM ile ilgili yaşanan olumsuzluklar ile ilgili velilerin görüşleri incelendiğinde; özellikle 1. yıl veliler (\%66) olmak üzere bütün veli gruplarında yüksek oranda BİLSEM ile ilgili olumsuzluk yaşamadıkları bulgusuna ulaşılmıştır. Söz edilen olumsuzluklara bakıldığında ise genel olarak zaman probleminin göze çarptığı görülmektedir. Zaman problemi ile ilgili olarak ortaya çıkan sonucun çocukların hem BİLSEM hem de okula gitmekte zorlanması konusunda Koç (2016) çalışmasının sonuçları ile örtüştüğü görülmüştür. Benzer şekilde Sarı ve Öğülmüş (2014) çalışmalarında BİLSEM öğrencilerinin karşılaştıkları sorunların başında zamanlama konusunda problem yaşadıkları sonucuna ulaşmışlardır. Bunun yanı sıra yeni başlayan öğrenci velilerinin öğretmenlerin yeterli olmaları hakkında endişe duyduklarını ifade ettikleri bulgusuna ulaşılmıştır. Bu konuda ikinci yıl veli grubunun bu duruma daha az değindikleri görülmüştür. 3. y1l ve üzeri veli grubunun diğerlerine göre daha yüksek oranda $(\% 21,42)$ öğretmenlerin yeterliliği hakkında merak ve endişelerini dile getirdikleri bulgusuna ulaşılmıştır. Alanyazın incelendiğinde BİLSEM öğretmen yeterliliği konusunda beklentilerin olduğu görülmektedir. Sarıtaş, Çatal ve Şahinbaş (2019), Kaya (2013), Kurnaz (2014) araştırmaları da velilerin öğretmenlerin de özel olması gerektiğini düşündüklerini belirten bulgularıyla örtüşmektedir. Koç (2016) ise araştırmasında velilerin görüşlerine göre; üstün yeteneklilerin eğitimi konusunda BİLSEM öğretmenlerin yeterince bilgi ve deneyime sahip olduklarını, kendilerini geliştirmede azimli ve özverili olduklarını, öğrencileri ve ailelerini anladıklarını onlarla iletişim becerilerinin iyi olduğu sonucuna ulaşmıştır. Yavuzyılmaz (2012), tezinde velilerin BİLSEM öğretmenlerine güvendiklerini $(\% 70,15)$ sonucuna ulaşmıştır. Yapılan araştırmalarda genel olarak velilerin BİLSEM öğretmenleri konusunda farklı görüşlere sahip oldukları görülmektedir. Üstün zekâlı öğrencilerin gerek kişilik, gerekse zihinsel farklılıklarından doğan ihtiyaçlarını karşılayabilecek kalitede ve nitelikte öğretmenlerin yetiştirilmesi, üzerinde titizlikle çalışılması gereken bir konudur (Kurnaz, 2014:9). Bu bağlamda BİLSEM'e yönelik Özel Eğitim ve Rehberlik Hizmetleri Genel Müdürlüğü, 2015 yılından itibaren BİLSEM sayılarının artırılması, kadrolu öğretmen alımlarının yapılması ve öğretmenler için bütün branşlarda çalıştay, eğitim faaliyetleri düzenlenmesi gibi çalışmalar gerçekleştirilmiştir. Bununla birlikte özel yetenekli öğrencilerin eğitiminde kullanılan eğitim metodolojilerine yönelik her yönüyle donanımlı öğretmenler yetiştirilerek BİLSEM öğretmen standartlarının oluşturulması önerilebilir. Karakuş (2010) 
çalışmasında, Bilim ve sanat merkezi ile ilgili yaşanan güçlükleri incelendiğinde en fazla yer verilen sorunun ulaşım ve ikinci sıklıkta yaşanan sorunun ise, merkeze devam ile ilgili olduğunu belirtmektedir. Çamdeviren (2014) tezinde özel yetenekli çocukların bilim ve sanat merkezine devamlarında ulaşım güçlüğü yaşadıklarını belirtmektedir. Bu çalışmada ise devam ile ilgili herhangi bir ulaşım sorunu yaşandığı bulgusuna ulaşılmamıştır. Bunun dışında BİLSEM'de ilk yılı olan ve 3. yıl ve üzeri velilerin öğrenciler için yorucu olduğu düşüncesinde oldukları göze çarpmaktadır. Bildiren ve Türkkanı (2013) ve Sarıtaş, Çatal ve Şahinbaş (2019) çalışmaları da bu sonuç ile örtüşmektedir. Bu hususta özel yetenekli öğrencilerin tüm eğitimlerini tek bir okulda alabildikleri ilkokul, ortaokul ve lise düzeyinde okulların açılması yönünde düzenlemeler yapilabilir.

Öğrencilerin BİLSEM'e devam etme sebepleri ile ilgili genel olarak veli gruplarının çocuk için faydalı olduğuna dair görüşleri öne çıkmaktadır. Bunun yanı sıra okul hayatında ve sınavlarda ek puan getirme ya da burs imkanı sağlanması gibi beklentilerin de olduğu görülmüştür. Kurnaz (2014) araştırmasında benzer şekilde öğrencilerin özel yetenekli olması nedeni ile bazı hakların verilmesi ya da imtiyazların sağlanmasının veliler tarafından beklendiği sonucuna ulaşmıştır. AlZoubi (2011) çalı̧̧masında ise velilerin, öğrencilerin yeteneklerine değil akademik başarılarına önem verdiklerini sonucuna ulaşmıştır (Akt: Al-Zoubi ve Rahman, 2015). Velilerin Türkiye eğitim sistemi içerisinde okul seçimleri ve meslekleri konusunda başarı ölçütlerinin olduğu sınavlara göre belirlendiğini düşündüğümüzde, bu görüşlerin ortaya çıkması olağan sayılabilmektedir.

Veliler, özel yetenekli çocuk ebeveyni olmanın gurur verici olmasının yanı sıra sorumluluk ve özveri gerektirdiğini ifade etmişlerdir. Sarıtaş, Çatal ve Şahinbaş (2019), çalışmalarında çocuklarının BİLSEM'de eğitim almalarının veliler için bir mutluluk olduğu sonucuna ulaşmışlardır. BİLSEM velisi olmanın mutluluk kaynağı olması ile gurur vermesi bulgusu bu bağlamda benzerlik göstermektedir. Ayrıca üç yıl ve üzerinde olan BİLSEM velilerinin çocuklarından çok fazla beklenti duyduklarını belirttikleri göze çarpmaktadır. Kurnaz (2014), veliler tarafından öğrencinin özel yetenekli olması nedeni ile bazı hakların verilmesi ya da imtiyazların sağlanmasının beklendiğini belirtmektedir. Benzer şekilde Karakuş (2010) ve Koç'un (2016) yaptıkları çalışmalar ile velilerin beklentilerinin fazla olduğu sonucunu desteklemektedir.

Özel yetenekli bir çocuğa sahip olmakla ilgili yaşanılan güçlüklere ilişkin veriler incelendiğinde; velilerin genel olarak yetersiz kalma, sorulara cevap verememe, çocukların çok fazla soru sormaları, iletişim sıkıntısı gibi sorunlar yaşadıklarını dile getirmişlerdir. Bunun dışında sorun yaşamadıklarını ifade eden velilerin sayısının da oldukça fazla olduğu söylenebilir. Çamdeviren (2014) tezinde çocukların çok sayıda ve sıklıkla soru sordukları ve anne babaların çocuklarının bir çok sorusuna cevap veremedikleri ve çoğunlukla bu durum karşısında kendilerini çaresiz hissettikleri sonucuna ulaşmıştır. Bununla birlikte özel yetenekli çocukların aşırı güven, kendini beğenme, mükemmeliyetçilik, başarısızlığı kabul etmeme ve bilgiçlik taslama gibi özellikler nedeniyle arkadaşlarıyla ve çevresiyle iletişim problemleri yaşadıkları da ifade etmektedir. Alkan (2013) araştırmasında; velilerin çocuklarının okulda, evde, toplum içinde yaşadığı sorunlar ile ilgili görüşleri alındığında kimi veliler çocuklarının sakin, uyumlu bir çocuk olduğunu ifade ederken kimi veli ise çocuklarının hareketli olduklarını, çok soru sorduklarını belirtmişlerdir. Karakuş (2010) ise yaptığı çalışmada davranışsal sorunları özel yetenekli çocukların sahip oldukları nitelikler nedeni ile sınıf arkadaşları ve aile üyeleri ile iletişimde çatışma yaşadıklarını belirtmekte ve sorununun nedenlerini mükemmeliyetçilik, arkadaşlık ilişkilerinde seçicilik gibi nedenlere dayandırmaktadır. Çavuşoğlu ve Semerci (2015) ise bu araştırma sonuçlarının tersine Bilim ve Sanat Merkezide eğitim gören çocukların velilerinin büyük bir kısmının çocukları ile iletişim sorunu yaşamadıklarını belirtmiştir. Özetle alanyazın incelendiğinde ailelerin özel yetenekli çocuklar ile benzer sorunlar yaşadıkları söylenebilir. Özel yetenekli çocukların 
karakteristik özellikleri düşünüldüğünde (eş zamanlı olmayan gelişim, aşırı duyarlılık, mükemmeliyetçilik vb.) toplum içinde birtakım sorunlar yaşamaları herkesçe kabul gören bir düşüncedir (Öztabak, 2018). Bu doğrultuda Oğurlu ve Yaman (2010) bu yaşanan sorunlara istinaden ailelerin, öğretmenlerin ve diğer yetişkinlerin üstün zekâlı ve yetenekli çocukların akranlarından farklı özelliklerini kabul edip ve bunları kabul ederek başarı ve sosyalleşme merdiveninde tırmanmalarında ellerinden tutmalarını gerektiğini belirtmektedir. Bununla birlikte Sarı'ya (2013) göre özel yetenekli öğrencilerin aileleri için aile eğitim programları hazırlanarak ailelerin doğru uygulamalar yapmalarına katkı sağlanmalıdır.

BILSEM tanılaması öncesi ailelere ev içerisinde öğrenci ile ilgili yaptıkları farklı etkinliklerin neler olduğu sorulduğunda çoğunluk olarak zekâ gelişimine yönelik faaliyetlere yer verdikleri görülmüş̧ür. Kaçar (2016) araştırmasında, özel yetenekli çocuk velilerinin büyük bir çoğunluğunun, çocukları için okul öncesi dönemde eğitim olanağı olarak kaynak ve materyal kullandıklarını belirtmektedir. Veliler evde çocukları ile evde vakit geçirirken zekâ oyunları, Legolar, kitaplar, bilimsel içerikli çocuk dergileri, dikkat geliştirici setler vb. kaynak ve materyal kullandıklarından bahsetmişlerdir. Bu bağlamda BİLSEM'e başlayıncaya kadar özel yetenekli çocukların ebeveynleri ile birlikte ilgi, yetenek ve kapasitelerini geliştirici kaliteli zaman geçirmeleri oldukça önemlidir. $\mathrm{Bu}$ şartlar dikkate alındığında, özel yetenekli çocukların tanılaması daha erken yaşlara çekilebilir. Ayrıca ailelerin tanılama öncesi özel yetenekli çocukları ile ev içerisinde geçirdikleri zaman diliminde neler yaptığına dair farklı araştırmalar yapılabilir.

Araştırma sonuçları BİLSEM'in öğrenci gelişiminde; araştırma yapmayı öğrenme, proje üretme, zekâ ve düşünme becerilerinde değişim, yeni arkadaşlar edinme, sosyalleşme, özgüven, girişimcilik, okul derslerine faydalı olması gibi etkileri olduğunu göstermektedir. Bu sonuçlar 1. Yıl veli grubu için henüz beklenti düzeyindedir. Velilerin BİLSEM'i okul derslerine faydalı bir kurum şeklinde görerek beklenti içinde olmaları Çetin ve Doğan (2018) yaptıkları çalışma sonuçları ile benzer niteliktedir. Sarıtaş, Çatal ve Şahinbaş (2019) çalışmalarında velilerin gözüyle BİLSEM'in, özgüven, farklı düşünme, merak, yaratıcılık, boş zamanlarını değerlendirme gibi farklı yönlerden katkı sağladığı ifade edilmekte olup araştırma bulgularını desteklemektedir.

Öğrencilerin örgün eğitime devam ettikleri okulda bulunan öğretmenlerin özel yetenekli çocuklar ile ilgilenme düzeylerine ilişkin veli görüşleri incelendiğinde; velilerin çoğunluğunun örgün eğitimdeki öğretmenlerinden memnun olduğu görülmüsstür. Bu konuda öğretmenlerin oldukça ilgili ve destek sağlamakta olduklarını ifade etmişlerdir. Bunun yanı sıra bazı velilerin ise örgün eğitimdeki öğretmenlerin özel yetenek konusunda yetersiz olduklarını düşündüklerini ifade eden görüşler de bulunmaktadır. Kurnaz, Tüybek ve Taşkesen (2009) araştırmalarında sınıf öğretmenlerinin özel yetenekli öğrenciler hakkında yeterli bilgilerinin olmadığı, özel yetenekli öğrencilere uygun öğretim etkinlikleri planlama ve uygulama açısından yetersiz oldukları ve konuda eğitim almaları gerektiğini ifade etmektedirler. Benzer şekilde Karakuş (2010) araştırmasında, üstün yetenekli çocukların ortak özellikleri, sınıf öğretmenlerinin üstün yetenekli öğrencilerle ilgili yeterince bilgi ve deneyime sahip olmamaları, öğretmen, akran ve diğer velilerle iletişim gibi konularda sorun yaşadıkları sonucuna ulaşmıştır. Coşkun ve Güleç (2018) ise araştırmalarında velilerin BİLSEM dışındaki örgün eğitimde yaşadı̆̆ güçlükleri incelendiğinde, örgün eğitim öğretmenleri tarafından öğrencilerin üstün yetenekli olmalarının doğası gereği oluşan ego merkezli kişilikleri dolayısıyla ödev yapmak gereği duymadıkları da ifade ettikleri sonucuna ulaşmıştır. Ev ödevleri yerine özel yetenekli öğrenciler için farklı uygulamalar yapmaları adına bu yönüyle sınıfında BILLSEM öğrencisi olan örgün eğitim öğretmenlerine yönelik eğitim verilmesi ya da bu konuda bir eylem araştırmasının yapılması önerilebilir. 


\section{KAYNAKÇA}

Alkan, A. (2013). Bilim Sanat Merkezine (BİLSEM) Giden Öğrencilerde Velilerinin Gördükleri Farklılıklar2. CICE 2013.

Al-Zoubi, S. M., and Rahman, M. S. B. A. (2015). Talented students' satisfaction with the performance of the gifted centers, Journal for the Education of Gifted Young Scientists, 4(1), 1-20.

Bakioğlu, A., and Levent, F. (2013). Suggestions for gifted education in Turkey. Üstün Yetenekli Eğitimi Araştırmaları Dergisi (Journal of Gifted Education Research), 1(1), 31-44.

Bildiren, A., ve Türkkanı, B. (2013). Üstün yetenekli öğrencilerin perspektifinden bilim ve sanat merkezlerinin hoş ve hoş olmayan özellikleri ve değişiklik talepleri, Üstün Yetenekli Eğitimi Araştırmaları Dergisi, 2013, 1(2), 128-135.

Ciğerci, C. Z. (2006). Üstün yetenekli olan ve olmayan ergenlerde benlik saygısı, başkalarının algılaması ve psikolojik belirtiler arasındaki ilişkiler: Fen lisesi ve düz lise karşılaştırması. Yayınlanmamış Yüksek Lisans Tezi. Sakarya Üniversitesi Sosyal Bilimleri Enstitüsü, Sakarya.

Coşkun, B. ve Güleç, E. E. (2018). Uyum Programı Öğrenci Velilerinin Bilim Sanat Merkezi Hazır Bulunuşluk Seviyeleri (İzmir İli Örneği), In Congress Proceedıngs Full Text Paper, s: 76.

Çamdeviren, Ş. (2014). Bilim ve Sanat Merkezine (Bilsem) Devam Eden Üstün Yetenekli Çocuklarm Anne Babalarının Karşılaştıkları Güçlükler, Yayımlanmamış Yüksek Lisans Tezi. Sakarya Üniversitesi, Eğitim Bilimleri Enstitüsü, Sakarya.

Çavuşoglu, M., ve Semerci, N. (2015). Anne Babaların BİLSEM'e Devam Eden Özel Yetenekli Çocuklarına İlişkin Görüşleri (Bartın İli Örneği), Bartın Üniversitesi Eğitim Fakültesi Dergisi, 325.

Çelikten, Y. (2017). Üstün Yetenekli Çocuklar ve BİLSEM, Turkish Journal of Educational Studies, 4(3): 87-104.

Çetin, A., ve Doğan, A. (2018). Bilim ve Sanat Merkezlerinde Görev Yapan Matematik Öğretmenlerinin Karşılaştıkları Sorunlar, Ankara Üniversitesi Eğitim Bilimleri Fakültesi Özel Eğitim Dergisi, 19(4), 615-641.

Çitil, M. (2018). Türkiye'de Üstün Yeteneklilerin Eğitimi Politikalarının Değerlendirilmesi, Milli Eğitim Dergisi, 47(Özel Sayı 1), 143-172.

Gökdemir, S. (2017). Ülkemizde Özel Yetenekli Öğrencilerin Tanılama Sürecinin Öğretmen, Veli ve Öğrenci Görüşlerine Göre Değerlendirilmesi, Yüksek Lisans Tezi, Necmettin Erbakan Üniversitesi, Konya.

Kaçar, M. (2016). Üstün Yetenekli Çocukların Ailelerinin Okul Öncesi Eğitim Hizmetlerine İlişkin Görüşleri, V. Sakarya'da Eğitim Araştırmaları Kongresi, Sakarya. s:45.

Karakuş, F. (2010). Üstün yetenekli çocukların anne babalarının karşılaştıkları güçlükler, Mersin Üniversitesi Eğitim Fakültesi Dergisi, 6(1), 127-144.

Karasar, N. (2004). Bilimsel araştırma yöntemi. Ankara: Nobel Yayınevi.

Keskin, M. Ö., Samancı N. K., ve Aydın S. (2013). Bilim ve sanat merkezleri: Mevcut durumları, sorunları ve çözüm önerileri, Üstün Yetenekli Eğitimi Araştırmaları Dergisi, 1(2), 78-96.

Kaya, N. G. (2013). Üstün yetenekli öğrencilerin eğitimi ve BİLSEM'ler, Erzincan Üniversitesi Eğitim Fakültesi Dergisi, 15(1), 115-122.

Koç, İ. (2016). Üstün zekâlı ve üstün yetenekli öğrenci velilerinin bilim ve sanat merkeziyle ilgili görüşleri: Bir BİLSEM örneği, Üstün Zekâhlar Eğitimi ve Yaratıcllık Dergisi, 3(3), 17-24. 
Kurnaz, A., Tüybek, C., ve Taşkesen, Ü. S. (2009). Sınıf öğretmenlerinin üstün yetenekli öğrencilere ilişkin görüş ve uygulamaları, Üstün Yetenekli Çocuklar Ulusal Kongresi, Anadolu Üniversitesi, Eskişehir. s:81.

Kurnaz, A. (2014). Yirminci y1lında bilim ve sanat merkezlerinin raporlar ve yönetici görüşlerine dayalı olarak değerlendirilmesi, Üstün Yetenekliler Eğitimi Araştırmaları Dergisi, 2(1), 1-22.

MEB, (2016). MEB Bilim ve Sanat Merkezleri Yönergesi, https://orgm.meb.gov.tr/meb_iys_dosyalar/2017_01/02031535_tebligler_dergisi.pdf

Oğurlu, Ü., ve Yaman, Y. (2010). Üstün zekâl1/yetenekli çocuklar ve iletişim, Pamukkale Üniversitesi Eğitim Fakültesi Dergisi, 28(28), 213-223.

Özbay, Y. (2013) Üstün Yetenekli Çocuklar ve Aileleri, Ankara: T.C. Aile ve Sosyal Politikalar Bakanlığı yayınları.

Öztabak, M. Ü. (2018). Ozzel/Ustün Yetenekli C,ocukların Ailelerine Yönelik Rehberlik ve Psikolojik Danışmanlık, Eğitim Ve İnsani Bilimler Dergisi: Teori ve Uygulama, 9(17), 79-106.

Sak, U., Ayas, M. B., Sezerel, B. B., Öpengin, E., Özdemir, N. N., ve Gürbüz, S. D. (2015). Gifted and Talented Education in Turkey: Critics and Prospects/Türkiye'de Üstün Yeteneklilerin Egitiminin Elestirel Bir Degerlendirmesi, Türk Üstün Zekâ ve Egitim Dergisi, 5(2), 110-132.

Sarı, H. (2013). Türkiye'de Üstün Yetenekli Çocukların Eğitim Gördüğü Bilim ve Sanat Merkezleri için Öneriler, Üstün Yetenekliler Eğitimi Araştırmaları Dergisi, 1(2), 146-149.

Sarı H., ve Öğülmüss, K. (2014). Bilim ve sanat merkezlerinde (BİLSEM) karşılaşılan sorunların öğretmen ve öğrenci görüşleri açısından değerlendirilmesi, Uluslararası Türk Eğitim Bilimleri Dergisi, 2(2) 254-265.

Sarıtaş, E., Şahin, Ü., ve Çatalbaş, G. (2019). Velilerin Gözüyle BİLSEM, Eğitimde Nitel Araştırmalar Dergisi, 7(1), 114-133.

Şahin, F., ve Kargın, T. (2013). Sınıf öğretmenlerine üstün yetenekli öğrencilerin belirlenmesi konusunda verilen bir eğitim programının etkililiği, Ankara Üniversitesi Eğitim Bilimleri Fakültesi Özel Ĕ̆gitim Dergisi, 14(2), 1-23

Yavuzyılmaz, B. (2012). Bilim ve Sanat Merkezlerine Devam Eden 7-11 Yaş Üstün Yetenekli Çocuklara Verilecek Sanat Eğitiminin Niteliği, Yayımlanmamış Yüksek Lisans Tezi, Ondokuz Mayıs Üniversitesi, Samsun.

Yıldırım, A. ve Şimşek, H. (2005). Sosyal Bilimlerde Nitel Araştırma Yöntemleri, Ankara: Seçkin Yayınevi. 